\title{
GRANULOMETRIC INFLUENCE ON THE COMBUSTION OF CHARCOAL FOR BARBECUE ${ }^{1}$
}

\author{
Ananias Francisco Dias Júnior ${ }^{2}$, José Otávio Brito ${ }^{3}$ e Carlos Rogério Andrade ${ }^{4}$
}

\begin{abstract}
The present work analyzed characteristics of charcoal used for barbecue and mainly took interest in the influence of the granulometry in the combustion process. The material have been tested for four different grain size $(8,16,32$ and $50 \mathrm{~mm})$ following a combustion test called combustion index (ICOM $\left.{ }_{\mathrm{cv}}\right)$, which takes in consideration time processing, temperature generated and the mass consumed. The characterization of charcoal was done according to the following parameters, moisture, apparent density, grain density, volatile materials content, ash content, fixed carbon content and calorific value. The proofed charcoal presented standard indicators for use in barbecue and was noticed the relationship between granulometric analysis and the $\mathrm{ICOM}_{\mathrm{cv}}$. The $16 \mathrm{~mm}$ grain size charcoal sample showed the best results for combustion. By contrast, the largest grain size sample presented lower results compared to the other samples. Thus, establishing unprecedented quantitative indicators in relation to those observed in practice, regarding the influence of grain size on the efficiency of combustion of the charcoal when used for barbecue.
\end{abstract}

Key words: Biomass energy; Charcoal quality for barbecue; Combustion index.

\section{INFLUÊNCIA DA GRANULOMETRIA NA COMBUSTÃo DO CARVÃO VEGETAL UTILIZADO PARA COCÇÃO DE ALIMENTOS}

\begin{abstract}
RESUMO - O objetivo deste estudo foi analisar as características do carvão vegetal utilizado para fins de cocção de alimentos, principalmente quanto à influência granulométrica no processo de combustão. Analisouse o material em quatro diferentes granulometrias $(8,16,32$ e $50 \mathrm{~mm})$, através de um ensaio de combustão, denominado ICOM ${ }_{c v}$, em que foram considerados o tempo de processo, a temperatura gerada e a massa consumida. Para a caracterização do carvão vegetal, determinaram-se a umidade, densidade aparente, densidade a granel, teor de materiais voláteis, teor de cinzas, teor de carbono fixo e poder calorifico. O carvão vegetal analisado apresentou indicativos regulares para uso na cocção de alimentos. Houve relação entre as granulometrias analisadas e o ICOM ${ }_{c v}$. O carvão com granulometria de $16 \mathrm{~mm}$ apresentou os melhores resultados diante da combustão. Em contrapartida, a maior granulometria analisada apresentou resultado inferior, em comparação com as demais granulometrias. Estabeleceram-se, assim, indicativos quantitativos inéditos daquilo que tem sido observado na prática, no que diz respeito à influência da granulometria na eficiência da combustão do carvão vegetal, quando este é usado na cocção de alimentos.
\end{abstract}

Palavras chaves: Energia de biomassa; Qualidade do carvão vegetal para cocção; Índice de combustão.

\footnotetext{
${ }^{1}$ Recebido em 13.11.2014 aceito para publicação em 21.10.2015.

${ }^{2}$ Universidade de São Paulo, Escola Superior de Agricultura "Luiz de Queiroz", Programa de Pós-Graduação em Recursos Florestais, Piracicaba, SP - Brasil. Email:<ananiasjr@usp.br>.

${ }^{3}$ Universidade de São Paulo, Escola Superior de Agricultura "Luiz de Queiroz", Departamento de Ciências Florestais, PiracicabaSP - Brasil. Email: <jobrito@usp.br>.

${ }^{4}$ Universidade de São Paulo, Escola Superior de Agricultura "Luiz de Queiroz", Programa de Pós-Graduação em Recursos Florestais, Piracicaba, SP - Brasil. Email: <crandrade@usp.br>.
} 


\section{INTRODUCTION}

Charcoal is a fuel used since ancient times for various purposes. Currently, it is used as much in the industrial sector, like steel industry, cement and glass, as in the household for barbecue. Warnes (2008), mentioned that cooking was the first essay of food preparation ever done by humankind.

Although the biggest producer of charcoal, most of the feedstock of Brazil is intended for industrial use. However, the country still keeps a strong tradition of using it for barbecue, as Arantes (2009) and Cintra (2009) reported the residential sector consumes $8 \%$ of all charcoal produced in the country, followed by the commercial sector $1.1 \%$, represented by pizzerias, bakeries and steakhouses. However, it is worth noting that for some developing countries, such as Haiti, charcoal is one of the main energy source in food preparation.

Researches conducted in Brazil related to the quality of charcoal have been mainly targeted on the steel industry demand, due to stronger economic nature of charcoal which is involved in this production chain. Consequently, there are few studies focused on analysis of charcoal for the purpose of cooking and barbecue.

According to Brito (2002), Ribeiro and Vale (2006) and Rosa et al. (2012), to be considered of good quality for home use, charcoal shall meet features like high relative bulk density, high fixed carbon content, high calorific value, low moisture, low content of volatile materials and low ash content.

In United States, for instance, the studies on the quality of the barbecue charcoal and its related aspects (WARNES, 2008) longstanding exist. In Europe, the "Association Française de Normalisation-AFNOR" established in 2005 a standard defined as "Appliances, solid combustibles and charcoal lighter for barbecue" describing quality issues for charcoal and briquettes used for barbecue. In Brazil, the only official proposal covering specifically charcoal quality control for barbecue, comes from the Secretariat of Agriculture and Supply of São Paulo State. Named "Selo São Paulo - Carvão Premium" (Sao Paulo Seal-Premium Quality Charcoal), it has been enacted by Resolution NÚ. 10 SAA of 11 July 2003. It aims to establish a quality standard for household charcoal, whose indicators among others are moisture, fixed carbon content, volatile material content, ash content, size of parts, labor needed (SÃO
PAULO, 2003). Based on voluntary membership such a stamp would be ensuring the quality of the charcoal production for barbecue based on the latter requirements.

One can cast doubt on the quality Standard pattern of charcoal for cooking, due to the difficulty of the carbonization control in most of stoves, the raw material differing from one to another in density, moisture, chemical composition, friability, mechanical resistance, reactivity and hygroscopicity. Furthermore, the result of the analysis of solid fuels should be interpreted with caution. They are influenced by the size and the shape of the material and moreover by the features of their raw material (QUIRINO; BRITO, 1991).

Despite the several underlined uncertainties about the quality definition of the charcoal for barbecue use, the enrichment of references on the issue is fundamental for the best valorization of the product regarding the end user. Thus, there is a strong probability that the grain size has a strong influence on the charcoal combustion process during the barbecue. Furthermore it has to be noticed that the packaging of the product itself, often, contains different grain size considering as powder.

In that sense the present work focused on the characterization of charcoal for barbecue purposes, mainly regarding its behavior during combustion process and the grain size influence.

\section{MATERIAL AND METHODS}

\subsection{Characterization of the charcoal}

The charcoal was collected in a charcoal factory located in the Atibaia area in the State of São Paulo. The company produces charcoal for barbecue from Eucalyptus spp wood, in a range of seven to ten years old. The charcoal production used masonry kilns, named "rabo quente", literally "hot ass" regarding the temperature around $500{ }^{\circ} \mathrm{C}$ reached in the main phase of the combustion process. Twenty bags of $2.5 \mathrm{~kg}$ of charcoal were collected, from those that would be distributed in the retail sector.

Working with packaged charcoal for the retailers ensured the randomness of the sampling and let us approach as much as possible what the end user get. With regard to initial characterization of the product, some analyzes were performed by following these rules: 
- Moisture content (\%) - NBR 8112 (ABNT, 1986).

-Apparent density ( $\left.\mathrm{g} \mathrm{cm}^{-3}\right)$ - NBR 11941 (ABNT, 2003).

- Grain density ( $\left.\mathrm{kg} \mathrm{m}^{-3}\right)$ - NBR 6922 (ABNT, 1981).

- Immediate analysis: volatile content, ash content, fixed carbon content (\%) - NBR 8112 (ABNT, 1986).

- Calorific value - NBR 8633 (ABNT, 1984).

\subsection{Index of combustion of charcoal grill $\left(\operatorname{ICOM}_{\mathrm{cv}}\right)$}

The ICOM was determined using the methodology developed by Quirino and Brito (1991) for briquettes of charcoal fines. It was necessary to adapt the assay for charcoal and to set the end time of the test, as the one required for complete combustion of the material (few minutes after beginning the assay). Such an adjustment was made due to the fact charcoal has a lower density than the briquettes assessed by the authors. The rest of the procedures followed every last details of the original methodology. As part of the set, a digital thermometer to measure the temperatures reached during combustion and scale with a capacity of $2.5 \mathrm{~kg}$ and a precision of $0.5 \mathrm{~g}$ were used.

The volume of the combustor $\left(1.25 \mathrm{dm}^{3}\right)$ was filled with a charcoal mass of $150 \pm 10 \mathrm{~g}$. The temperature and mass consumption were recorded every five minutes, from the start of the experiment, set as zero until the end of the test. The combustion index of charcoal, called $\mathrm{ICOM}_{\mathrm{cv}}$ in this research, was calculated according to Eq. 1.

$$
I C O M c v=\frac{A x B}{100} x C
$$

Where: $\mathrm{A}=$ is a percentage corresponding to the test time in which the temperature remained above $150^{\circ} \mathrm{C}$ on the total time ( $\mathrm{min}$ ) of combustion $(\%) ; \mathrm{B}=$ is the percentage of the maximum temperature reached in the test compared to $150{ }^{\circ} \mathrm{C}(\%) ; \mathrm{C}=$ is the percentage of the total mass consumed generating temperatures above $150^{\circ} \mathrm{C}$.

Observation: Conformed to the original methodology, the temperature of $150^{\circ} \mathrm{C}$ is the minimum one required to start the cooking process on a barbecue, comprising the food dewatering stage.

In order to simulate everyday household situations that may be encountered during barbecue (combining several charcoal particle sizes in a single package), charcoal was passed in five different sieves with particle size mesh $8,16,32$ and $50 \mathrm{~mm}$ in adequation with the volume capacity of the combustor.

The data obtained from the combustion experiment were submitted to the Kolmogorov-Smirnov test at a significance level of $5 \%$ to check the standard distribution of the data. The nearness of variances was checked to the same level of significance applying the Levene's test, whose one of the assumptions of variance analysis is that the variances are equal in the analyzed category. Once corroborated, the tests were driven following a completely randomized design with five replicates per treatment (sizing). The variance analysis was carried out with the aid of Minitab ${ }^{\circledR} 16$ software and the Scott-Knott test at 5\% significance level was used as multiple comparison test.

\section{RESULTS}

\subsection{Characteristics of the charcoal}

Table 1 shows the average values obtained for the tests conducted to characterize the charcoal.

\subsection{Combustion index $\left(\mathrm{ICOM}_{\mathrm{cv}}\right)$}

Analyzing the behavior of charcoal during combustion in Figure 1, one can observed that the maximum temperature reached varied according to grain size and showed the same tendency once plot over time. The average values contained in Table 2 show statistically differences.

The Figure 2 illustrates the mass consumption during combustion. Note that the particle size of 50 $\mathrm{mm}$ charcoal consumed a smaller mass percentage during the assay and more uniform mass loss. Paula et al. (2011) evaluating charcoal ICOM of unknown grain size, observed as well the uniformity along of the burning and of the material weight loss.

The Figure 3 presents the average values for a

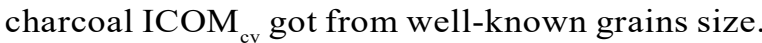

\section{DISCUSSION}

\subsection{Characteristics of the charcoal}

The results of the analysis of charcoal have permitted to feature it as a classical product with regular for barbecue characteristics for the consumer market. A high coefficient of variation for the ash content was 
Table 1 - Characteristics of the analyzed charcoal.

Tabela 1 - Características do carvão vegetal analisado.

\begin{tabular}{lcc}
\hline Variables & Average & Coefficient of variation (\%) \\
\hline Moisture (\%) & 3.93 & 16.9 \\
Apparent density $\left(\mathrm{g} \mathrm{cm}^{-3}\right)$ & 0.32 & 5.26 \\
Grain density $\left(\mathrm{kg} \mathrm{m}^{-3}\right)$ & 219 & 1.11 \\
Content of volatile materials (\%) & 16.9 & 10.91 \\
Ash content $(\%)$ & 1.20 & 42.55 \\
Fixed carbon content (\%) & 81.9 & 2.89 \\
Calorific value $\left(\mathrm{kcal} \mathrm{kg}^{-1}\right)$ & 7805 & 6.44 \\
\hline
\end{tabular}

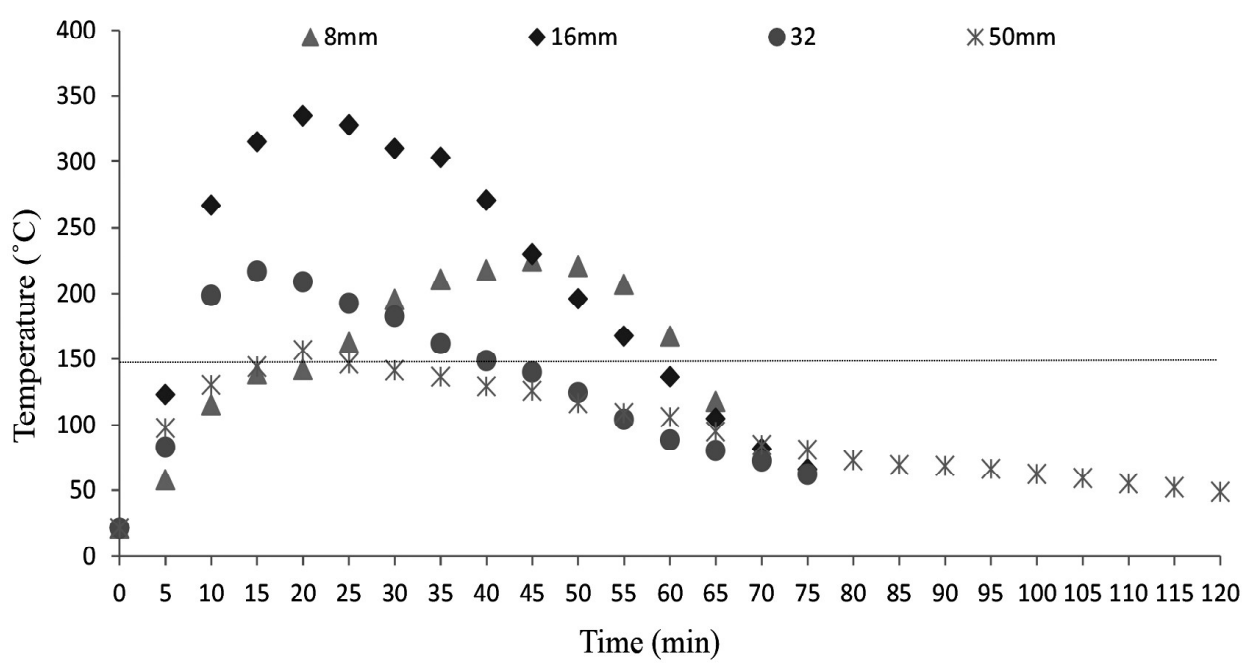

Figure 1 - Variation of temperature versus time during the combustion.

Figura 1 - Variação da temperatura em função do tempo durante o teste de combustão.

Table 2 - Maximum temperature (T. Max) and final temperatures (T.F.) reached during the combustion test of charcoal.

Tabela 2 - Temperaturas máximas (T. Max) e temperaturas finais (T.F.) alcançadas no teste de combustão do carvão vegetal.

\begin{tabular}{ccc}
\hline Grain size $(\mathrm{mm})$ & T. Max. (ÚC) & T. F. (ÚC) \\
\hline 8 & $239 \mathrm{~b}_{(12.45)}$ & $25 \mathrm{~b}_{(8.32)}$ \\
16 & $319 \mathrm{a}_{(10.94)}$ & $27 \mathrm{~b}_{(6.30)}$ \\
32 & $232 \mathrm{~b}_{(4.56)}$ & $26 \mathrm{~b}_{(2.25)}$ \\
50 & $229 \mathrm{~b}_{(21.57)}$ & $47 \mathrm{a}_{(4.37)}$
\end{tabular}

Average values followed by the same letter in the bar chart do not differ in the Scott-Knott test at 5\% significance level. Values in parenthesis correspond to the coefficients of variation.

noticed, however Trugilho et al. (2005) report it as usual for this kind of product and probably related to multiple factors. The other analyzed characteristics are consistent with the values obtained by Brito et al. (1982), Quirino and Brito (1991), São Paulo (2003), Andrade and Machado
(2004), Trugilho et al. (2005), Oliveira et al. (2010), Neves et al. (2011), Rosa et al. (2012), Carneiro et al. (2014) and Dias Junior et al. (2015).

\subsection{Index of combustion}

The Figure 1 and Table 2 report that the $16 \mathrm{~mm}$ grain size charcoal had the highest maximum temperature, while the $50 \mathrm{~mm}$ particle size one showed the lowest one. In the statistical field, the 8,32 and $50 \mathrm{~mm}$ grain sizes of charcoal are grouped together, as differing from the others. The maximum temperature value for the $50 \mathrm{~mm}$ grain size can be related to its dimension. Indeed, under such size there are less contact between parts, giving a much less efficient energy transfer between them not allowing to constitute the "block continuous" of mass combustion generally expected with smaller grain size. Practically, in the $50 \mathrm{~mm}$ case, parts are burning individually, disconnected from the heat supply. 


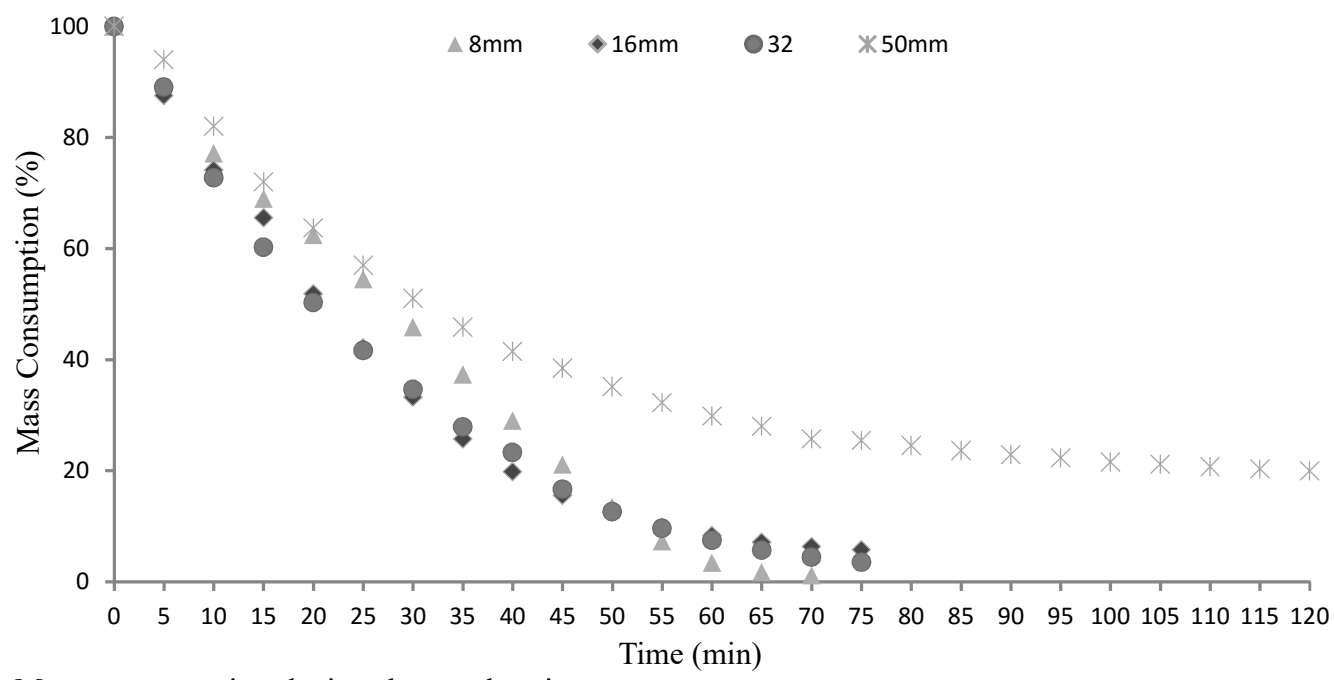

Figure 2 - Mass consumption during the combustion.

Figura 2 - Consumo de massa durante o teste de combustão.

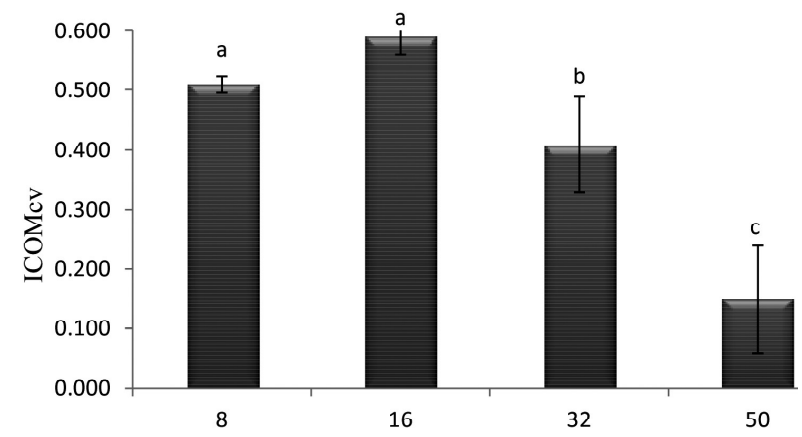

Figure 3 - Combustion index of analyzed grain sizes. Average values with same letter in the bar chart do not differ in the Scott-Knott test with a 5\% significance.

Figura 3 - Índice de combustão das granulometrias analisadas. Valores médios seguidos pela mesma letra na coluna não diferem entre si, pelo teste de Scott-Knott a $5 \%$ de significância.

As Figure 2 shows, even with a low mass consumption, the largest charcoal grains $(50 \mathrm{~mm})$ have a similar tendency as particles from other sizes, even if it takes it more time to lose mass during heating generation. According to Quirino and Brito (1991), for cooking use, it is interesting to maintain a given constant temperature, even if inappropriate in case of abrupt changes, which may foster frequent interferences in the process, for example feeding the combustion to keep it.

It can be also noticed that the 8,16 and $32 \mathrm{~mm}$ charcoal grain size degradated between 70 and 75 minutes after starting the test, whereas the larger grain size charcoal $(50 \mathrm{~mm})$ achieved complete degradation only after 120 minutes duration of the test.

It is interesting to analyze the values of ICOM from the perspective of the combustion behavior illustrated in Figure 1, which represents the references of temperature versus time. It is to note that maintaining the temperature above $150{ }^{\circ} \mathrm{C}$ is highly relevant considering Equation 2. In fact, the $16 \mathrm{~mm}$ grain size charcoal present clearly the largest area under a curve (Figure 1) and therefore the greatest $\mathrm{ICOM}_{\mathrm{cv}}$.

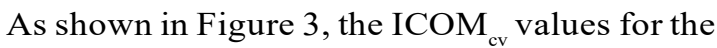
grain sizes of 8, 16 and $32 \mathrm{~mm}$ are in agreement with the values obtained by Quirino and Brito (1991). The authors found values from 0.31 to 1.23 . It is observed that the highest value of ICOM $_{c v}$ was for charcoal grain size of $16 \mathrm{~mm}$. From which one can deduce that the higher the $\mathrm{ICOM}_{\mathrm{cv}}$, the greater the heat generation with the least fuel consumption mass relative to a given time.

In general, if a fuel releases enough energy (heat quantity) during combustion, but, counterpart, consumes too much mass to generate this energy, its ICOM will be lower. This occurred for charcoal with a $8 \mathrm{~mm}$ grain

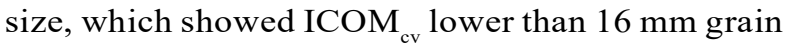
size charcoal, despite the differences between them were not statistically significant. The charcoal with the grain size of $32 \mathrm{~mm}$ occured with the third ICOM value.

Revista Árvore, Viçosa-MG, v.39, n.6, p.1127-1133, 2015 
When the combustion refers to charcoal with large particle sizes, as with the $50 \mathrm{~mm}$ charcoal, the ICOM $_{\mathrm{cv}}$ value got significantly lower than the others. It let infer that due to the size of its parts, the contact between them was very small, which probably would have lessened the energy transfer throughout the mass under combustion. Despite slower mass loss rate (Figure 2), on the other hand, the temperature ranged in most of the case, below the minimum one required for use in barbecue.

The results of research provide us with the direction that, in fact, there would be arguments for considering the grain size of charcoal as an important characteristic in the product qualification proposition for use in barbecue. Similarly, by controlling the granulometry could be proposed to define the choice of charcoal, depending on the type of behavior that is desired during cooking, commanded by type of heat needs to be demanded by the food being prepared. This aspect opens up the prospect of new researches in the area, combining the quality of the charcoal and the type of cooking that it will be required.

\section{CONCLUSION}

The analyzed charcoal had regular features for use in barbecue. In the combustion test, the charcoal of $16 \mathrm{~mm}$ grain size was the one with the highest maximum temperature and the highest value of $\mathrm{ICOM}_{\mathrm{cv}}$. Charcoal $50 \mathrm{~mm}$ had the worst behavior in the combustion test.

It is then recommended for the combustion tests of charcoal used for barbecue to establish a grain size standard and test time for a better evaluation of the material.

\section{ACKNOWLEDGMENTS}

The authors acknowledge the Trade and Industry Charcoal São Manoel Ltda for providing the material for the study, the Research Group Bioenergy and Bioproducts From Forests from the Forest Sciences Department of the College ofAgriculture "Luiz de Queiroz" - ESALQ, of University of São Paulo - USP, Brazil, for their support and trials and the Brazilian governement agency of Coordination for the Improvement of Higher Education Personnel (CAPES) and the Institute of Forestry Research and Studies (IPEF) for the scholarship grants awarded.

\section{BIBLIOGRAPHY}

ANDRADE, A.M.; MACHADO, F.S. Comparação entre as propriedades físicas e mecânicas dos finos de carvão vegetal e de carvão mineral, para injeção nas ventaneiras de altos-fornos siderúrgicos. Biomassa \& Energia, v.1, n.3, p.273-279, 2004.

ARANTES, M.D.C. Variação das características da madeira e do carvão de um clone de Eucalyptus grandis W. Hill ex Maiden x Eucaylptus urophylla S. T. Blake. 2009. 149f. Tese (Doutorado em Ciência e Tecnologia da Madeira) - Universidade Federal de Lavras, Lavras, 2009.

\section{ASSOCIAÇÃO BRASILEIRA DE NORMAS} TÉCNICAS - ABNT. NBR 6922/81: carvão vegetal - Ensaios físicos determinação da massa específica (densidade à granel). Rio de Janeiro: 1981.

ASSOCIAÇÃO BRASILEIRA DE NORMAS TÉCNICAS - ABNT. NBR 11941. Madeira Determinação da densidade básica. Rio de Janeiro: 2003.

ASSOCIAÇÃO BRASILEIRA DE NORMAS TÉCNICAS - ABNT. NBR 8112 - Carvão vegetal: análise imediata. Rio de Janeiro: 1986. 5p.

ASSOCIAÇÃO BRASILEIRA DE NORMAS TÉCNICAS - ABNT. NBR 8633: carvão vegetal - determinação do poder calorífico. Rio de Janeiro: 1984. 13p.

\section{ASSOCIATION FRANÇAISE DE}

NORMALISATION - AFNOR. NF EM 1860-2-

Appareils, combustibles solides et allumebarbecue pour la cuisson au barbecue. Saint Denis, Paris: 2005. 29p.

BRITO, J.O. A escolha certa do carvão. Revista Churrasco e Churrascarias, v. 5, n.24, p.16, 2002.

BRITO, J. O.; BARRICHELO, L. E. G.; MURAMOTO, M. C.; COUTO, H. T. Z. Estimativa da densidade a granel do carvão vegetal a partir de sua densidade aparente. Piracicaba: IPEF, 1982. 6p. (Circular técnica, 150). 
CARNEIRO, A. C. O.; CASTRO, A. F. N. M.; CASTRO, R. V. O.; SANTOS, R. C.; FERREIRA, L. P.; DAMÁSIO, R. A. P.; VITAL, B. R. Potencial energético da madeira de Eucalyptus sp. em função da idade e de diferentes materiais genéticos. Revista Árvore, v.38, n.2, p.375$381,2014$.

CINTRA, T.C. Avaliações energéticas de espécies florestais nativas plantadas na região do Médio Paranapanema, SP. 2009. 84f. Dissertação (Mestrado em Recursos Florestais) - Escola Superior de Agricultura "Luiz de Queiroz" - ESALQ/USP, Piracicaba, 2009.

DIAS JÚNIOR, A.F.; ANDRADE, C.R.; BRITO, J.O.; MILAN, M. Desdobramento da função de qualidade (QFD) na avaliação da qualidade do carvão vegetal utilizado para cocção de alimentos. Floresta \& Ambiente, v.22, n.2, p.262-270, 2015.

NEVES, T. A.; PROTÁSIO, T. P.; COUTO, A. M.; TRUGILHO, P. F.; SILVA, V. O.; VIEIRA, C. M. M. Avaliação de clones de Eucalyptus em diferentes locais visando à produção de carvão vegetal.

Pesquisa Florestal Brasileira, v. 31 , n.68, p.319-330, 2011.

OLIVEIRA, A. C.; CARNEIRO, A. C. O.; VITAL, B. R.; ALMEIDA, W.; PEREIRA, B. L. C.; CARDOSO, M. T. Parâmetros de qualidade da madeira e do carvão vegetal de Eucalyptus pellita F. Muell. Scientia Forestalis, v.38, n.87, p.431-439, 2010.

PAULA, L.E.R.; TRUGILHO, P.F.; REZENDE, R.N.; ASSIS, C.O.; BALIZA, A.E.R. Produção e avaliação de briquetes lignocelulósicos.

Pesquisa Florestal Brasileira, v. 31, n.61, p.103-112, 2011.

QUIRINO, W.F.; BRITO, J.O. Características e índice de combustão de briquetes de carvão vegetal. Brasília: Laboratório de Produtos Florestais-LPF, 1991. 14p. (Série técnica, 13).

RIBEIRO, P.G.; VALE, A.T. Qualidade do carvão vegetal de resíduos de serraria para o uso doméstico. In: REUNIÃO ANUAL DA SOCIEDADE BRASILEIRA PARA O PROGRESSO DA CIÊNCIA, 2006, Florianópolis. Anais... Florianópolis: Universidade Federal de Santa Catarina, 2006.

ROSA, R. A.; ARANTES, M. D. C.; PAES, J. B.; ANDRADE, W. S. P.; MOULIN, J. C. Qualidade do carvão vegetal para uso doméstico. Journal of Biotecnology and Biodiversity, v.3, n.2, p.41-48, 2012.

SÃO PAULO (Estado). Secretaria de Agricultura e Abastecimento de São Paulo. Resolução $\mathbf{n}^{\circ} \mathbf{1 0}$ SAA, de 11 de jul. de 2003.

TRUGILHO, P. F.; SILVA, J. R. M.; MORI, F. A.; LIMA, J. T.; MENDES, L. M.; MENDES, L. F. B. Rendimentos e características do carvão vegetal em função da posição radial de amostragem em clones de Eucalyptus. Cerne, v.11, n.2, p.178$186,2005$.

WARNES, A. Savage barbecue: race, culture and the invention of america's first food. Georgia, United Stats: British Library, Georgia, 2008. 201 p. 
